Wheat with slight to severe 2,4-D injury, left to right.

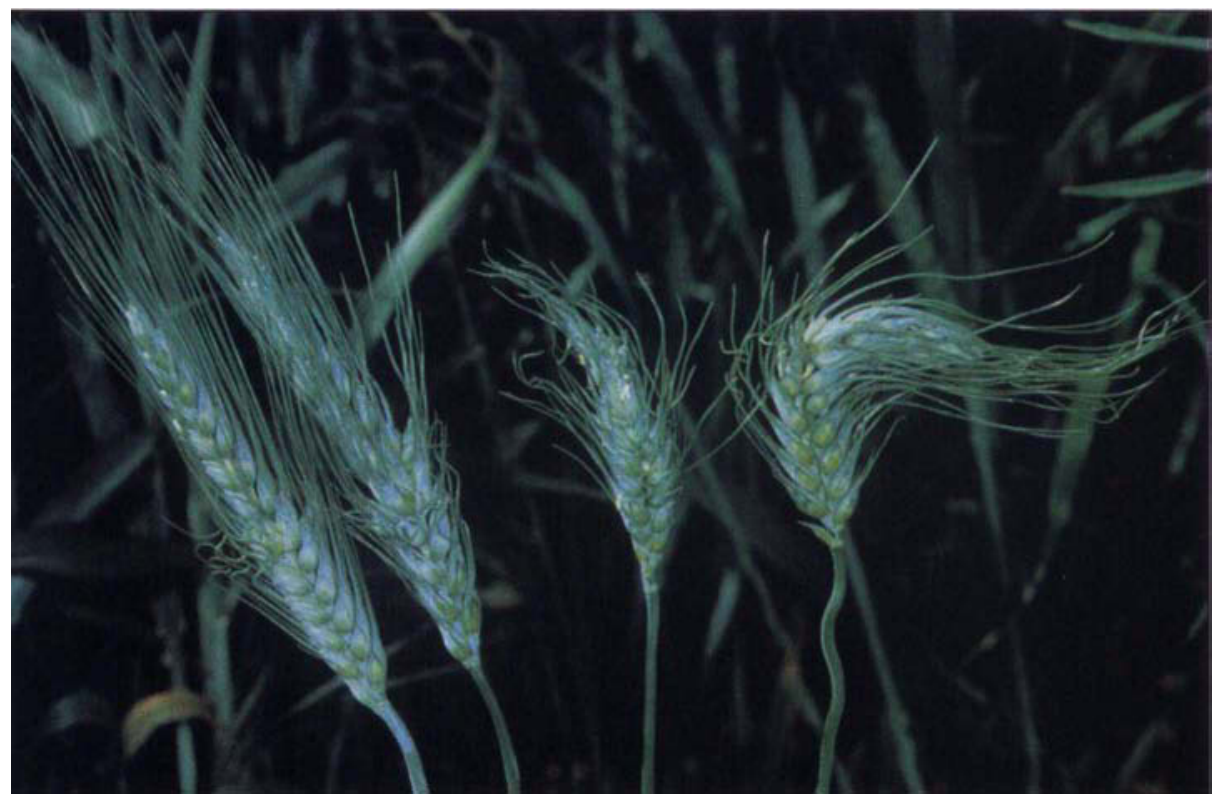

\title{
Postemergence herbicides and application time affect wheat yields
}

\begin{abstract}
Jack P. Orr $\square \quad$ Mick Canevari
Experiments conducted on wheat grown in the Sacramento and San Joaquin valleys found that two of the most critical factors in reducing plant injury are choice of postemergence herbicide and the growth stage at which the herbicide is applied. To minimize risk of wheat injury and to maximize yields, the optimal time to apply postemergence herbicides is at the tillering growth stage. The two-leaf stage is most sensitive to 2,4-D. Moderate or severe injury caused by 2,4-D and dicamba + MCPA on one-third to one-half of spikes can cause yield losses of up to $27 \%$.
\end{abstract}

Wheat is an important crop in California, grown on more than 500,000 acres in the Sacramento and San Joaquin valleys. Predominant cultivars in the Sacramento Valley are 'Yolo', 'Anza' and 'Express', while 'Yecora Rojo' is the main cultivar in the San Joaquin Valley. In past years, various fields have shown injury from postemergence applications of the phenoxy and benzoic herbicides, 2,4-D and dicamba, respectively, as well as MCPA combined dicamba. Grain heads and awns (beards) show various degrees of malformation, or epinasty, ranging from slight to severe. The cause of injury and its effect on grain yields are unclear.

In the past, the amount of yield loss in wheat due to grain head injury from postemergence herbicides has been
Ryan Carner $\square$ Gail Nishimoto

very difficult to estimate. Symptoms of herbicide injury in commercial fields varied from slight to severe; however, prior to this study, the relationship between visual injury symptoms and yield had not been made.

We investigated the effects of several postemergence herbicides on grain injury and yields. Our research included rate of application and timing (by wheat stage of growth) of

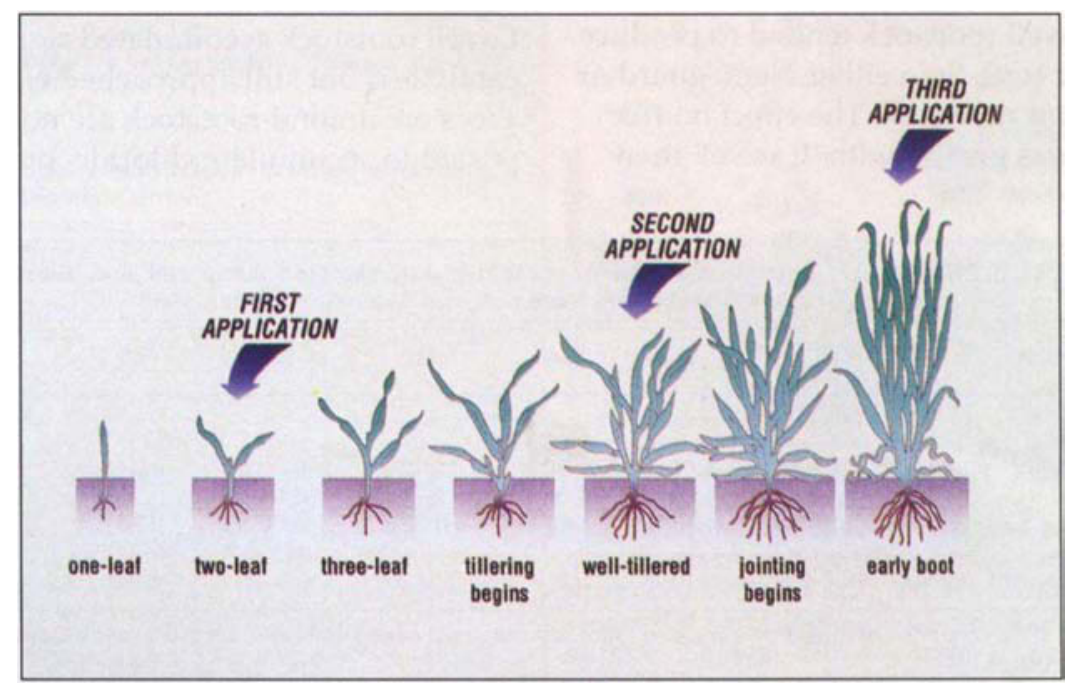

Fig. 1. Growth stages of wheat. 


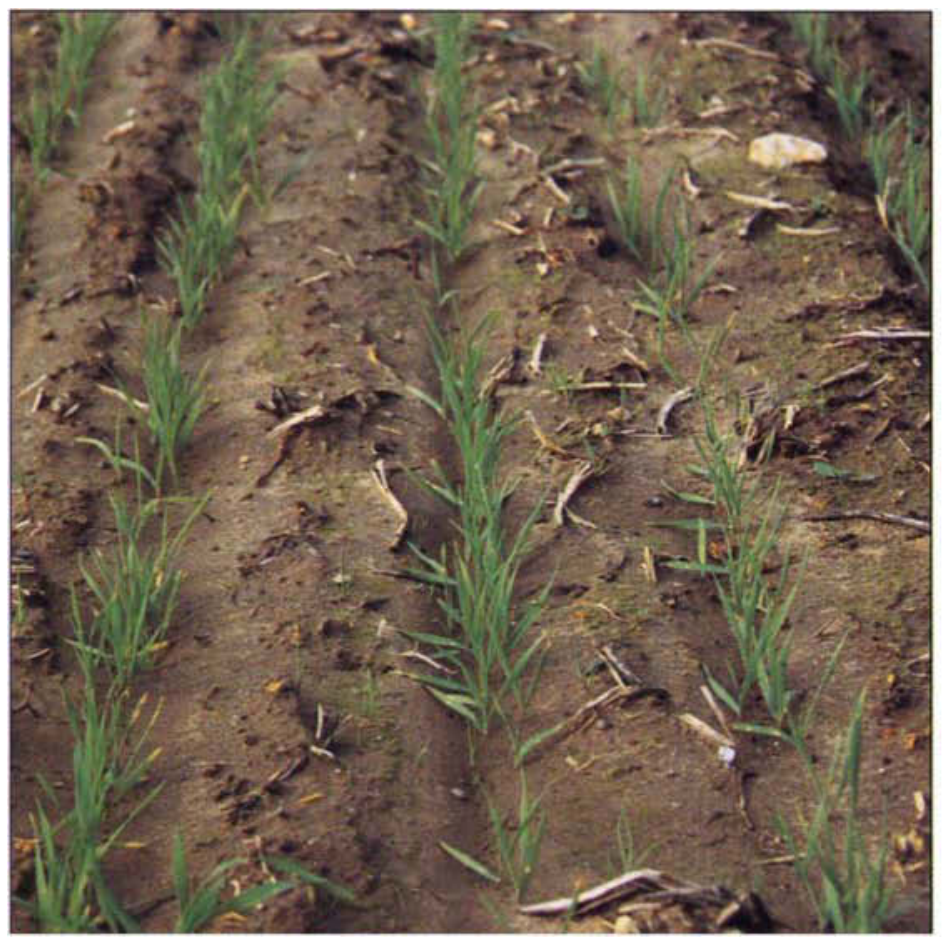

At the 2-3 leaf stage, wheat is at the most susceptible stage for 2,4-D damage.

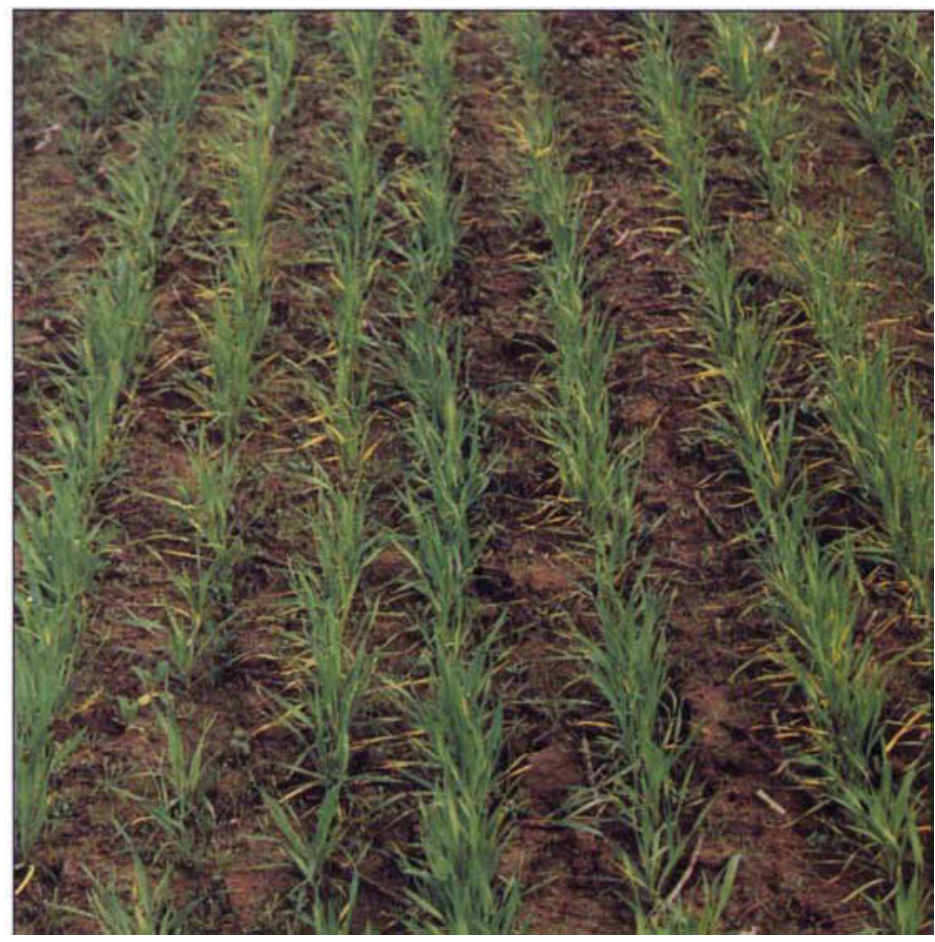

For least amount of risk of damage, the tiller stage is the most appropriate stage for 2,4-D treatment. Beyond the tiller stage, risk increases. herbicide applications to various cultivars. We studied five different wheat cultivars to determine interactions between different herbicides and cultivars at various growth stages. Experiments were conducted from 1990 to 1993 on the Lewellen Ranch on Tyler Island in the Sacramento-San Joaquin Delta, and at the UC Davis Agronomy Farm from 1993 to 1994.

\section{Application stages}

Hard red spring cultivars 'Serra', 'Yolo', 'Anza' and 'Express', and a hard white, 'Klasic', were planted with a grain drill in the fall of 1989, 1990 and 1991. 'Yolo' and 'Anza' were planted in 1992, and 'Yolo' and 'Express' in 1993. The wheat was grown under winter rainfall, supplemented by irrigation in the spring. The Tyler Island site was on an Egbert muck soil with spud ditches for irrigation; the UC Davis site, located on a Yolo fine sandy loam, was furrow irrigated. Starter fertilizer 11-52-0 was applied under the seed at both sites at a rate of $80 \mathrm{lb} / \mathrm{ac}$. The Tyler Island site had a top dressing of $25 \mathrm{lb} / \mathrm{ac}$ of nitrogen as urea at tiller growth stage. At the UC
Davis site, $80 \mathrm{lb} / \mathrm{ac}$ of nitrogen was applied prior to planting, followed by $62 \mathrm{lb} / \mathrm{ac}$ of nitrogen at the tiller growth stage. Plots were harvested at maturity with a small plot harvester and grain yields were determined.

The experimental design was a split-split plot in four randomized complete blocks. Main plot treatments were application times. Subplots were herbicide treatments, and sub-subplots were cultivars.

Chickweed, Stellaria media (L.), was the predominant weed species present at both locations. The population ranged from 10 to 30 plants per square foot. Miner's lettuce, Montia perfoliate, was also present at the UC Davis site

\begin{tabular}{|c|c|c|c|}
\hline \multirow{2}{*}{$\begin{array}{l}\text { Herbicide } \\
\text { Tyler Island }\end{array}$} & \multicolumn{2}{|c|}{ Growth stage* } & \\
\hline & Two-leaf & \multicolumn{2}{|c|}{ Tiller/elongation } \\
\hline $\begin{array}{l}\text { 2,4-D } \\
\text { Dicamba } \\
\text { MCPA } \\
\text { Dicamba + MCPA } \\
\text { Bromoxynil } \\
\text { Control }\end{array}$ & $\begin{array}{l}0.70 \\
0.125 \\
0.25 \\
0.125+0.25 \\
0.375 \\
-\end{array}$ & \multicolumn{2}{|c|}{$\begin{array}{l}0.93 \\
0.125 \\
1.0 \\
0.125+0.375 \\
0.5 \\
-\end{array}$} \\
\hline \multirow{2}{*}{$\begin{array}{l}\text { Herbicide } \\
\text { UCD }\end{array}$} & \multicolumn{3}{|c|}{ Growth staget } \\
\hline & Two-leaf & Tiller & Elongation \\
\hline $\begin{array}{l}\text { Dicamba } \\
\text { 2,4-D } \\
\text { Bromoxynil } \\
\text { Bromoxynil + MCPA } \\
\text { Bromoxynil } \\
\text { Control }\end{array}$ & $\begin{array}{l}0.125 \\
0.70 \\
0.25 \\
0.25+0.25 \\
0.50\end{array}$ & $\begin{array}{l}b \text { ailac } \\
0.125 \\
0.70 \\
0.37 \\
0.37+0.75 \\
0.50 \\
-\end{array}$ & $\begin{array}{l}0.125 \\
0.93 \\
0.37 \\
0.50+1.0 \\
0.50\end{array}$ \\
\hline
\end{tabular}


with a population of 17 plants per square foot.

Herbicides were applied at various wheat growth stages using a $\mathrm{CO} 2$ backpack sprayer, $8002 \mathrm{E}$ flat fan nozzles, at a rate of 15 gallons of water per acre. The applications were made at three growth stages: two-leaf, fully tillered and the internode elongation stage between jointing and early boot (fig. 1). The lowest labeled herbicide rates (table 1) were used at the first wheat growth stages, when weeds were smallest, and increased to maximum label rates at the tillering and elongation stages when weeds were larger. Herbicide treatments consisted of 2,4-D-amine, dicamba, dicamba + MCPA, MCPA alone, and bromoxynil. Bromoxynil was not in the 1990 study, but replaced dicamba + MCPA in the 1993-1994 study. A higher rate of bromoxynil also replaced the MCPA treatment in the 1993-1994 study to

\begin{tabular}{|c|c|c|c|c|c|c|}
\hline \multicolumn{7}{|c|}{$\begin{array}{l}\text { TABLE 2. Wheat grain yields influenced by postemergence application time of herbicides } \\
\text { Sacramento-San Joaquin Delta, } 1992\end{array}$} \\
\hline \multirow[t]{2}{*}{ Stage } & Herbicide & Cultivars & $\begin{array}{l}\text { Head* } \\
\text { injury } \\
4 / 14\end{array}$ & $\begin{array}{c}\text { Degreet } \\
\text { of injury } \\
4 / 14\end{array}$ & $\begin{array}{l}\text { Heads } \\
\text { affected } \\
4 / 14\end{array}$ & $\begin{array}{c}\text { Yield } \\
7 / 10\end{array}$ \\
\hline & & & $\%$ & & $\%$ & $\mathrm{lb} / \mathrm{ac}$ \\
\hline \multirow[t]{18}{*}{ Two-leaf } & Dicamba & Serra & 0.3 & 0.3 & 0 & 7,469 \\
\hline & & Yolo & 1.0 & 1.3 & 20 & 6,900 \\
\hline & & Klasic & 0.3 & 0.3 & 0 & 7,420 \\
\hline & MCPA & Serra & 0.0 & 0.0 & 0 & 7,443 \\
\hline & & Yolo & 0.5 & 0.5 & 0 & 6,855 \\
\hline & & Klasic & 0.8 & 0.5 & 25 & 7,404 \\
\hline & 2,4-D & Serra & 3.0 & 3.0 & 48 & 6,075 \\
\hline & & Yolo & 2.0 & 2.3 & 33 & 5,560 \\
\hline & & Klasic & 3.0 & 3.0 & 45 & 6,484 \\
\hline & Dicamba + MCPA & Serra & 2.0 & 2.3 & 45 & 7,312 \\
\hline & & Yolo & 2.3 & 2.3 & 47 & 5,840 \\
\hline & & Klasic & 1.5 & 1.5 & 50 & 7,251 \\
\hline & Bromoxynil & Serra & 0.0 & 0.0 & 0 & 8,058 \\
\hline & & Yolo & 0.3 & 0.3 & 0 & 7,653 \\
\hline & & Klasic & 0.0 & 0.0 & 0 & 7,830 \\
\hline & Control & Serra & 0.0 & 0.0 & 0 & 7,312 \\
\hline & & Yolo & 0.0 & 0.0 & 0 & 7,095 \\
\hline & & Klasic & 0.0 & 0.0 & 0 & 7,153 \\
\hline \multirow[t]{18}{*}{ Tiller } & Dicamba & Serra & 0.3 & 0.3 & 0 & 7,408 \\
\hline & & Yolo & 2.0 & 1.5 & 50 & 6,722 \\
\hline & & Klasic & 0.3 & 0.3 & 0 & 6,912 \\
\hline & MCPA & Serra & 0.0 & 0.0 & 0 & 7,410 \\
\hline & & Yolo & 0.0 & 0.0 & 0 & 7,501 \\
\hline & & Klasic & 0.0 & 0.0 & 0 & 7,122 \\
\hline & $2,4-D$ & Serra & 0.0 & 0.0 & 0 & 7,402 \\
\hline & & Yolo & 3.0 & 1.5 & 92 & 7,215 \\
\hline & & Klasic & 0.0 & 0.0 & 0 & 7,467 \\
\hline & Dicamba + MCPA & Serra & 0.0 & 0.0 & 0 & 7,696 \\
\hline & & Yolo & 2.3 & 1.0 & 68 & 7,355 \\
\hline & & Klasic & 1.0 & 1.0 & 0 & 6,947 \\
\hline & Bromoxynil & Serra & 0.0 & 0.0 & 0 & 7,674 \\
\hline & & Yolo & 0.3 & 0.3 & 0 & 7.333 \\
\hline & & Klasic & 0.0 & 0.0 & 0 & 7,607 \\
\hline & Control & Serra & 0.0 & 0.0 & 0 & 7,676 \\
\hline & & Yolo & 0.5 & 0.5 & 0 & 7,327 \\
\hline & & Klasic & 0.0 & 0.0 & 0 & 7,278 \\
\hline \multirow[t]{18}{*}{ Elongation } & Dicamba & Serra & 0.0 & 0.0 & 0 & 7,844 \\
\hline & & Yolo & 0.5 & 0.8 & 0 & 7,606 \\
\hline & & Klasic & 0.5 & 0.5 & 0 & 7,271 \\
\hline & MCPA & Serra & 0.0 & 0.0 & 0 & 7,731 \\
\hline & & Yolo & 0.0 & 0.0 & 0 & 7,589 \\
\hline & & Klasic & 0.0 & 0.0 & 0 & 7,856 \\
\hline & 2,4-D & Serra & 0.0 & 0.0 & 0 & 7,501 \\
\hline & & Yolo & 0.0 & 0.0 & 0 & 7,456 \\
\hline & & Klasic & 0.0 & 0.0 & 0 & 7,530 \\
\hline & Dicamba + MCPA & Serra & 0.0 & 0.0 & 0 & 7,743 \\
\hline & & Yolo & 0.5 & 1.0 & 0 & 7,754 \\
\hline & & Klasic & 0.0 & 0.0 & 0 & 7,658 \\
\hline & Bromoxynil & Serra & 0.0 & 0.0 & 0 & 6,917 \\
\hline & & Yolo & 0.0 & 0.0 & 0 & 7,379 \\
\hline & & Klasic & 0.3 & 0.3 & 0 & 7,398 \\
\hline & Control & Serra & 0.0 & 0.0 & 0 & 7,642 \\
\hline & & Yolo & 0.3 & 0.3 & 0 & 7,225 \\
\hline & & Klasic & 0.3 & 0.3 & 0 & 7,640 \\
\hline \multicolumn{7}{|c|}{$\begin{array}{l}{ }^{0} 0=\text { no injury; } 1=\text { slight } 1-10 \% ; 2=\text { moderate } 11-25 \% ; 3=\text { severe }>25 \% \\
+0=\text { no injury; } 1=\text { slight; } 2=\text { moderate; } 3=\text { severe } \\
\ddagger D \text { uncan's multiple range test, LSD } 5 \% 606 \text { lbs }\end{array}$} \\
\hline
\end{tabular}

determine if these new treatments were more effective in reducing injury while still providing weed control. Visual ratings were made on a scale of 0 to 10 of chickweed and miner's lettuce control throughout the season. The three measurements made to determine extent of injury to grain heads were: 1) percent of total heads affected, 2) degree of injury to wheat spikes on a scale of 0 to 3 (severe), and 3 ) percentage of the head affected.

\section{Injury by growth stages, 1992}

In 1992 the herbicide treatment dicamba + MCPA applied at the twoleaf stage caused significant visual injury to the 'Serra', 'Klasic' and 'Yolo' cultivars. 'Klasic' was the least affected, with slight damage to $50 \%$ of the heads. 'Serra' and 'Yolo' showed moderate injury to $45 \%$ of heads. 'Yolo' was the only cultivar whose yield was reduced significantly, dropping from 7,095 lb/ac in the control to $5,840 \mathrm{lb} / \mathrm{ac}$ in the treated plot.

The 2,4-D treatment also resulted in significant visual injury to the wheat. 'Serra' and 'Klasic' had severe injury to $45 \%$ of heads, while 'Yolo' showed moderate injury across $33 \%$ of heads. Again, 'Yolo' yields were most affected with a $22 \%$ reduction, compared with $17 \%$ reduction for 'Serra' and $9.4 \%$ for 'Klasic' (table 2).

Dicamba caused slight injury only to 'Yolo' with $20 \%$ of the plants showing epinasty in the spikelets. However, there was no significant reduction in yield compared to the control.

At the tiller application stage, 'Yolo' was the only cultivar to show significant injury from dicamba, 2,4-D and dicamba + MCPA, with $92 \%$ of plants damaged by $2,4-\mathrm{D}, 68 \%$ by dicamba + MCPA and $50 \%$ by dicamba. Degree of injury was slight for all three herbicides; yield was significantly reduced by dicamba when compared to MCPA. There was no significant difference between dicamba and the other treatments (table 2).

Herbicides applied at the elongation stage did not result in any significant symptoms for the three cultivars. However, 'Serra' yield was significantly reduced from bromoxynil at 0.5 $\mathrm{lb}$ ai / ac (table 2). 


\section{Results by year}

In 1990, herbicide treatments 2,4-D and dicamba + MCPA were especially injurious to wheat when applied at the jointing growth stage. 'Yolo' yields were most affected, with a decrease of $1,062 \mathrm{lb} / \mathrm{ac}$ with $2,4-\mathrm{D}$, and $1,252 \mathrm{lb} / \mathrm{ac}$ with dicamba + MCPA, when compared to the control. Yield for 'Klasic' was down $19 \%$ from 2,4-D and $25 \%$ from dicamba + MCPA. 'Serra' yields were not affected (table 3 ).

In 1991, 2,4-D application at the two-leaf stage caused significant yield reduction to 'Serra' and 'Yolo.' Dicamba caused a $10.7 \%$ decrease in 'Serra' and $12.7 \%$ decrease for 'Yolo'. Overall, 'Yolo' was least affected by herbicides applied at any growth stage (table 4).

In 1992, 2,4-D application at the two-leaf stage was the most damaging to all three cultivars. Yields were significantly reduced for 'Serra', 'Yolo' and 'Klasic'. Application of dicamba + MCPA resulted in significant yield reduction for 'Yolo' at this stage (table 5).

In 1993, herbicides applied to 'Yolo' and 'Anza' at all three growth stages did not cause injury or significant differences in yield.

In 1994, the cultivars 'Yolo' and 'Express' were used, and herbicide treatments changed slightly. Bromoxynil + MCPA replaced dicamba + MCPA, and a higher rate of bromoxynil replaced the MCPA treatment. No significant interactions were detected between herbicide treatments, cultivars or growth stages. However, 2,4-D applications on cultivars at all growth stages resulted in a significant yield reduction $-6,334 \mathrm{lb} / \mathrm{ac}$ versus an average yield of $6,780 \mathrm{lb} / \mathrm{ac}$ for the other herbicide treatments (table 6).

\section{Injury minimized at tillering stage}

To minimize risk of wheat injury and maximize yields, the best time to apply postemergence herbicides is at the tillering growth stage.

Depending on the year and environmental conditions at the time of application, the two-leaf stage is the most sensitive time for applications of 2,4-D. However, judging from environmental data collected, there does not appear to be a single contributing factor (table 7). Results of 4 to 5 years of tests on 'Yolo' showed that 2,4-D applied at the two-leaf stage caused yield reductions of $20 \%(6,284 \mathrm{lb} / \mathrm{ac}$ compared with $7,158 \mathrm{lb} /$ ac for untreated plants, and 7,097 lb/ac for plants treated with bromoxynil). Application of 2,4-D, dicamba + MCPA or bromoxynil at the jointing growth stage sometimes resulted in injury or yield reductions to 'Serra', 'Yolo' and 'Klasic' (tables 3, 4 and 5).
Our research also found that growers do not have to treat wheat with an herbicide if chickweed or miner's lettuce are the primary weed species. In fact, there may be a risk of actually reducing yields, depending on the herbicide used and the growth stage of the wheat. In our experiments, grain yields for the nontreated controls were equal to or higher than grain yields for herbicide-treated wheat.

\begin{tabular}{|c|c|c|c|c|}
\hline \multicolumn{5}{|c|}{$\begin{array}{l}\text { TABLE 3. Wheat grain yields influenced by postemergence application times of herbicides } \\
\text { Sacramento/San Joaquin Delta, } 1990\end{array}$} \\
\hline \multirow[b]{2}{*}{ Cultivars } & \multirow[b]{2}{*}{ Herbicide } & \multicolumn{3}{|c|}{ Time of application } \\
\hline & & Two-leaf & Tillered & Jointing \\
\hline & & \multicolumn{3}{|c|}{................................ yield: Ib/ac ...................................... } \\
\hline Serra & $\begin{array}{l}\text { Dicamba } \\
\text { MCPA } \\
2,4-D \\
\text { Dicamba + MCPA } \\
\text { Control }\end{array}$ & $\begin{array}{l}6,700 \text { a } \\
6,994 \text { a } \\
7,202 \text { a } \\
6,907 \text { a } \\
6,517 \text { a }\end{array}$ & $\begin{array}{l}6,619 \mathrm{a} \\
6,804 \mathrm{a} \\
6,754 \mathrm{a} \\
6,859 \mathrm{a} \\
6,650 \mathrm{a}\end{array}$ & $\begin{array}{l}6,510 \mathrm{a} \\
6,756 \mathrm{a} \\
6,316 \mathrm{a} \\
6,084 \mathrm{a} \\
6,271 \mathrm{a}\end{array}$ \\
\hline Yolo & $\begin{array}{l}\text { Dicamba } \\
\text { MCPA } \\
2,4-D \\
\text { Dicamba + MCPA } \\
\text { Control }\end{array}$ & $\begin{array}{l}6,304 \mathrm{~b} \\
6,590 \mathrm{ab} \\
7,100 \mathrm{a} \\
6,855 \mathrm{ab} \\
6,670 \mathrm{ab}\end{array}$ & $\begin{array}{l}6,904 \mathrm{a} \\
7,156 \mathrm{a} \\
6,578 \mathrm{a} \\
6,746 \mathrm{a} \\
6,634 \mathrm{a}\end{array}$ & $\begin{array}{l}6,162 \mathrm{ab} \\
6,534 \mathrm{a} \\
5,666 \mathrm{bc} \\
5,476 \mathrm{c} \\
6,728 \mathrm{a}\end{array}$ \\
\hline Klasic & $\begin{array}{l}\text { Dicamba } \\
\text { MCPA } \\
2,4-D \\
\text { Dicamba + MCPA } \\
\text { Control }\end{array}$ & $\begin{array}{l}6,759 \mathrm{ab} \\
6,513 \mathrm{~b} \\
6,863 \mathrm{ab} \\
7,161 \mathrm{a} \\
6,478 \mathrm{~b}\end{array}$ & $\begin{array}{l}6,985 \text { a } \\
6,865 \text { a } \\
6,617 \text { a } \\
6,761 \text { a } \\
6,727 a\end{array}$ & $\begin{array}{l}6,033 a \\
6,118 \mathrm{a} \\
5,029 \mathrm{~b} \\
4,693 \mathrm{~b} \\
6,269 \mathrm{a}\end{array}$ \\
\hline \multicolumn{5}{|c|}{ LSD 5\% Duncan's multiple range } \\
\hline \multicolumn{5}{|c|}{$\begin{array}{l}\text { Serra Between herbicides for the same times of application } \\
\text { Yetween herbicides for the different times of application } \\
\text { Yelo Between herbicides for the same time of application } \\
\text { Klasic Between herbicides for the different times of application } \\
\\
\text { Between herbicides for the same time of application } \\
\text { Betwe different times of application }\end{array}$} \\
\hline \multicolumn{5}{|c|}{$\begin{array}{l}\text { TABLE 4. Wheat grain yields influenced by postemergence application times of herbicides } \\
\text { Sacramento/San Joaquin Delta, } 1991\end{array}$} \\
\hline & & \multicolumn{3}{|c|}{ Time of application } \\
\hline \multirow[t]{2}{*}{ Cultivars } & Herbicide & Two-leaf & Tillered & Jointing \\
\hline & & \multicolumn{3}{|c|}{ 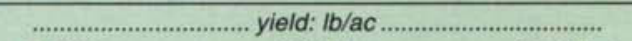 } \\
\hline Serra & $\begin{array}{l}\text { Dicamba } \\
\text { MCPA } \\
2,4-D \\
\text { Dicamba + MCPA } \\
\text { Bromoxynil } \\
\text { Ccontrol }\end{array}$ & $\begin{array}{l}8,965 a \\
8,755 a b \\
8,004 c \\
8,644 a b \\
8,816 a b \\
8,457 b\end{array}$ & $\begin{array}{l}8,343 \mathrm{bc} \\
8,499 \mathrm{abc} \\
8,272 \mathrm{bc} \\
8,131 \mathrm{c} \\
8,688 \mathrm{ab} \\
8,771 \mathrm{a}\end{array}$ & $\begin{array}{l}8,548 \text { bc } \\
8,892 a b \\
8,707 a b c \\
8,471 \mathrm{c} \\
8,970 \mathrm{a} \\
8,685 \mathrm{abc}\end{array}$ \\
\hline Yolo & $\begin{array}{l}\text { Dicamba } \\
\text { MCPA } \\
2,4-D \\
\text { Dicamba + MCPA } \\
\text { Bromoxynil } \\
\text { Control }\end{array}$ & $\begin{array}{l}8,595 \mathrm{a} \\
8,587 \mathrm{a} \\
7,406 \mathrm{~b} \\
8,297 \mathrm{a} \\
8,306 \mathrm{a} \\
8,605 \mathrm{a}\end{array}$ & $\begin{array}{l}7,985 \text { a } \\
8,139 \text { a } \\
8,227 \text { a } \\
8,028 \text { a } \\
8,251 \text { a } \\
8,465 \text { a }\end{array}$ & $\begin{array}{l}8,431 \text { a } \\
8,656 \text { a } \\
8,219 \text { a } \\
8,290 \text { a } \\
8,405 \text { a } \\
8,517 \text { a }\end{array}$ \\
\hline Klasic & $\begin{array}{l}\text { Dicamba } \\
\text { MCPA } \\
2,4-D \\
\text { Dicamba + MCPA } \\
\text { Bromoxynil } \\
\text { Control } \\
\end{array}$ & $\begin{array}{l}8,216 \mathrm{ab} \\
8,434 \mathrm{ab} \\
8,166 \mathrm{~b} \\
7,997 \mathrm{~b} \\
7,983 \mathrm{~b} \\
8,667 \mathrm{a}\end{array}$ & $\begin{array}{l}8,000 \mathrm{ab} \\
7,994 \mathrm{ab} \\
8,111 \mathrm{ab} \\
7,969 \mathrm{ab} \\
8,400 \mathrm{a} \\
7,812 \mathrm{~b}\end{array}$ & $\begin{array}{l}7,936 \mathrm{bc} \\
8,236 \mathrm{ab} \\
8,161 \mathrm{ab} \\
7,827 \mathrm{bc} \\
7,493 \mathrm{c} \\
8,411 \mathrm{a}\end{array}$ \\
\hline \multicolumn{5}{|c|}{ LSD 5\% Duncan's multiple range } \\
\hline Serra & $\begin{array}{l}\text { Between herbicides for the } \\
\text { Between herbicides for the }\end{array}$ & $\begin{array}{l}\text { time of application } \\
\text { ant times of application }\end{array}$ & $\begin{array}{l}418 \\
479\end{array}$ & \\
\hline Yolo & $\begin{array}{l}\text { Between herbicides for the } \\
\text { Between herbicides for the }\end{array}$ & $\begin{array}{l}\text { time of application } \\
\text { ent times of application }\end{array}$ & 497 & \\
\hline Klasic & $\begin{array}{l}\text { Between herbicides for the } \\
\text { Between herbicides for the }\end{array}$ & $\begin{array}{l}\text { time of application } \\
\text { ent times of application }\end{array}$ & 644 & \\
\hline
\end{tabular}




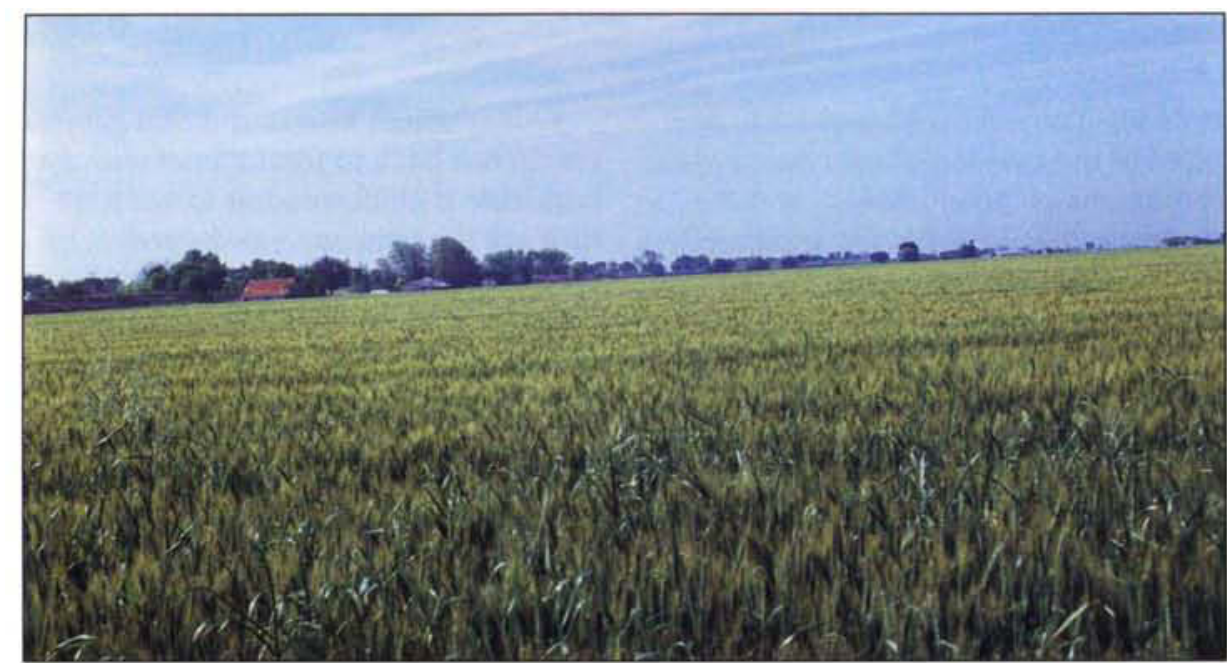

TABLE 5. Wheat grain yields influenced by postemergence application times of herbicides Sacramento/San Joaquin Delta, 1992

\begin{tabular}{|c|c|c|c|c|}
\hline \multirow[b]{2}{*}{ Cultivars } & \multirow[b]{2}{*}{ Herbicide } & \multicolumn{3}{|c|}{ Time of application } \\
\hline & & Two-leaf & Tillered & Jointing \\
\hline & & \multicolumn{3}{|c|}{ 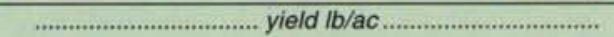 } \\
\hline Serra & $\begin{array}{l}\text { Dicamba } \\
\text { MCPA } \\
\text { 2,4-D } \\
\text { Dicamba + MCPA } \\
\text { Bromoxynil } \\
\text { Control }\end{array}$ & $\begin{array}{l}7,469 \mathrm{~b} \\
7,443 \mathrm{~b} \\
6,075 \mathrm{c} \\
7,312 \mathrm{~b} \\
8,058 \mathrm{a} \\
7,312 \mathrm{~b}\end{array}$ & $\begin{array}{l}7,408 \mathrm{a} \\
7,410 \mathrm{a} \\
7,402 \mathrm{a} \\
7,696 \mathrm{a} \\
7,674 \mathrm{a} \\
7,676 \mathrm{a}\end{array}$ & $\begin{array}{l}7,844 \mathrm{a} \\
7,731 \mathrm{a} \\
7,501 \mathrm{a} \\
7,743 \mathrm{a} \\
6,917 \mathrm{~b} \\
7,642 \mathrm{a}\end{array}$ \\
\hline Yolo & $\begin{array}{l}\text { Dicamba } \\
\text { MCPA } \\
2,4-D \\
\text { Dicamba + MCPA } \\
\text { Bromoxynil } \\
\text { Control }\end{array}$ & $\begin{array}{l}6,900 \mathrm{~b} \\
6,855 \mathrm{~b} \\
5,560 \mathrm{c} \\
5,840 \mathrm{c} \\
7,653 \mathrm{a} \\
7,095 \mathrm{ab}\end{array}$ & $\begin{array}{l}6,722 \mathrm{~b} \\
7,501 \mathrm{a} \\
7,215 \mathrm{ab} \\
7,355 \mathrm{a} \\
7,333 \mathrm{a} \\
7,327 \mathrm{a}\end{array}$ & $\begin{array}{l}7,606 \mathrm{a} \\
7,589 \mathrm{a} \\
7,456 \mathrm{a} \\
7,754 \mathrm{a} \\
7,379 \mathrm{a} \\
7,225 \mathrm{a}\end{array}$ \\
\hline Klasic & $\begin{array}{l}\text { Dicamba } \\
\text { MCPA } \\
2 \text { 2,4-D } \\
\text { Dicamba + MCPA } \\
\text { Bromoxynil } \\
\text { Control }\end{array}$ & $\begin{array}{l}7,420 \mathrm{ab} \\
7,404 \mathrm{ab} \\
6,484 \mathrm{c} \\
7,251 \mathrm{a} \\
7,830 \mathrm{a} \\
7,153 \mathrm{~b}\end{array}$ & $\begin{array}{l}6,912 \mathrm{~b} \\
7,122 \mathrm{ab} \\
7,467 \mathrm{ab} \\
6,947 \mathrm{~b} \\
7,607 \mathrm{a} \\
7,278 \mathrm{ab}\end{array}$ & $\begin{array}{l}7,271 \mathrm{~b} \\
7,856 \mathrm{a} \\
7,530 \mathrm{ab} \\
7,658 \mathrm{ab} \\
7,398 \mathrm{ab} \\
7,640 \mathrm{ab}\end{array}$ \\
\hline
\end{tabular}

LSD 5\% Duncan's multiple range test

Between herbicides for the same time of application

Between herbicides for the different times of application

565

606

TABLE 6. Herbicides applied at all growth stages*' to cultivars 'Yolo' \& 'Express', 1994-UCD

\begin{tabular}{lcc}
\hline \hline Herbicide & $\begin{array}{c}\text { Application } \\
\text { rate }\end{array}$ & Yield \\
\hline Bromoxynil + MCPA & $1 \mathrm{~b}$ ail/ac & $\mathrm{lb} / \mathrm{act}$ \\
Bromoxynil & $(0.375+0.25)-(0.5+1.0)$ & $6,902.4 \mathrm{a}$ \\
Bromoxynil & 0.375 & $6,838.7 \mathrm{a}$ \\
Dicamba & 0.50 & $6,705.2 \mathrm{a}$ \\
Control & 0.13 & $6,675.9 \mathrm{a}$ \\
$2,4-D$ & - & $6,593.0 \mathrm{a}$ \\
\end{tabular}

- Growth stages ranged from two-leaf to elongation. Lower rate at two-leaf

† Least significant difference at $5 \%$ level: $349 \mathrm{lb}$ Duncan's multiple range test

TABLE 7. Environmental data 1989-1993 November-March*

\begin{tabular}{lccc}
\hline \hline & \multicolumn{2}{c}{ Average } \\
\cline { 2 - 4 } Year & $\begin{array}{c}\text { Minimum mean } \\
\text { temperature }\end{array}$ & $\begin{array}{c}\text { Mean } \\
\text { temperature }\end{array}$ & Precipitation \\
\hline & ${ }^{\circ} \mathrm{F}$ & ${ }^{\circ} \mathrm{F}$ & inches \\
$89-90$ & 40.70 & 50.02 & 10.13 \\
$90-91$ & 38.26 & 49.50 & 11.63 \\
$91-92$ & 44.46 & 51.04 & 10.70 \\
$92-93$ & 41.04 & 50.02 & 21.18 \\
$93-94$ & 39.30 & 49.70 & 9.22 \\
\hline Sacramento Airport & & &
\end{tabular}

Proper timing of herbicide application to this Delta wheat field resulted in excellent grain heads and high yield.

There are significant differences in yield depending on which herbicide is used and at which growth stage the herbicide is applied. In regard to the Yolo cultivar, the amount of yield reduction depends on the degree of spike injury and the number of spikes affected. Slight injury covering a high percentage of spikes has little effect on yield, while moderate or severe injury to one-third to one-half of spikes caused by 2,4-D and dicamba + MCPA can cause yield losses of up to $27 \%$. Choice of herbicide can make a considerable difference in yield outcome: the bromoxynil treatment to Yolo, for instance, yielded $7,653 \mathrm{lb} /$ ac versus $5,560 \mathrm{lb} /$ ac with 2,4-D.

Several steps can be taken to reduce injury to wheat by postemergence herbicides:

- Use the appropriate herbicide for the weed species present.

- Apply phenoxy or benzoic + phenoxy herbicide combinations at the tillering growth stage to minimize injury.

- Use lower- to mid-range label rates when weeds are small and grain growth stage is less than full tiller.

- Dicamba, bromoxynil, or bromoxynil + MCPA present less risk to wheat when applied at the early (two-leaf) growth stage compared to 2,4-D or dicamba + MCPA.

Through a properly integrated weed management system, risk of injury is reduced and wheat yield increased.

J.P. Orr is County Director/Weed Science Advisor, Sacramento County UCCE; M. Canevari is Field Crops Farm Advisor, San Joaquin County UCCE; L. Jackson is Cereal Specialist, and R. Wennig is Staff Research Associate, Department of Agronomy and Range Science, UC Davis; $R$. Carner is part-time technician and student, Yuba City College, and Gail Nishimoto is Programmer/Analyst, DANR Analytical Lab, UC Davis. 